This item was submitted to Loughborough's Research Repository by the author.

Items in Figshare are protected by copyright, with all rights reserved, unless otherwise indicated.

\title{
Identity threats, identity work and elite professionals
}

PLEASE CITE THE PUBLISHED VERSION

http://dx.doi.org/10.1177/0170840615593594

\section{PUBLISHER}

SAGE Publications (@ the authors)

\section{VERSION}

AM (Accepted Manuscript)

\section{PUBLISHER STATEMENT}

This work is made available according to the conditions of the Creative Commons Attribution-NonCommercialNoDerivatives 4.0 International (CC BY-NC-ND 4.0) licence. Full details of this licence are available at: https://creativecommons.org/licenses/by-nc-nd/4.0/

\section{LICENCE}

CC BY-NC-ND 4.0

\section{REPOSITORY RECORD}

Coupland, Christine, and Andrew D. Brown. 2015. "Identity Threats, Identity Work and Elite Professionals". Loughborough University. https://hdl.handle.net/2134/18149. 


\title{
Identity Threats, Identity Work, and Elite Professionals
}

\author{
Andrew D. Brown \\ University of Bath \\ School of Management \\ Email: adb20@management.bath.ac.uk
}

\author{
Christine Coupland \\ Loughborough University \\ School of Business \& Economics \\ Email: $\underline{\text { C.Coupland@lboro.ac.uk }}$
}

\section{Accepted for publication, May 2015, Organization Studies}

\begin{abstract}
Elite professionals opportunistically employ threats to their work identities to author preferred selves. Predicated on understandings that identities are subjectively available to people as in-progress narratives, and that these are often insecure fabrications, we investigate the identity work of members of a UK-based professional Rugby League club. The research contribution we make is to demonstrate that professionals use identity threats as flexible resources for working on favoured identities. We show that rugby players authored identity threats centred on the shortness of their careers, injury, and performance, and how these were appropriated (made their own) by men to develop desired occupational and masculine identities. In so doing, we also contribute to debates on how professionals' identity discourse is an expression of agency framed within relations of power.
\end{abstract}

Discourse; Identity; Insecurity; Masculinity; Narrative; Power; Professional; Threat 


\title{
Identity Threats, Identity Work, and Elite Professionals
}

\begin{abstract}
Elite professionals opportunistically employ threats to their work identities to author preferred selves. Predicated on understandings that identities are subjectively available to people as in-progress narratives, and that these are often insecure fabrications, we investigate the identity work of members of a UK-based professional Rugby League club. The research contribution we make is to demonstrate that professionals use identity threats as flexible resources for working on favoured identities. We show that rugby players authored identity threats centred on the shortness of their careers, injury, and performance, and how these were appropriated (made their own) by men to develop desired occupational and masculine identities. In so doing, we also contribute to debates on how professionals' identity discourse is an expression of agency framed within relations of power.
\end{abstract}

\section{Key words}

Discourse; Identity; Insecurity; Masculinity; Narrative; Power; Professional; Threat 


\section{Introduction}

How do elite professionals employ threats to their work identities in their authorship of preferred selves? It is well established that individuals, including both shop floor workers (Collinson, 1992) and professionals (Learmonth \& Humphreys, 2012), attempt to manage threats to their identities. These studies show that employees draw on their work activities to construct identities they regard as important, valued and meaningful (Alvesson and Willmott, 2002), but that these are often threatened, may be ambiguous or contested, and are frequently fragile and insecure (Collinson, 2003; Humphreys, 2005). Less attention, however, has been devoted to people's construal of identity threats. This is important because it is by attending to how threats are talked about that we can better understand how they are used opportunistically as a resource for identity work. We analyse how sportsmen talked about threats to their player identities which they appropriated (made use of) to author preferred occupational and masculine identities. Our principal interest is in discourse, 'the structured collections of texts embodied in ...practices of talking and writing' (Grant et al 2004, p.3), as discourse is the principal '... means by which organization members create a coherent social reality that frames their sense of who they are' (Mumby \& Claire, 1997, p.181).

A loose federation of allied literatures dealing with identity threat (Petriglieri, 2011), dirty work (Ashforth \& Kreiner, 1999), workplace bullying (Lutgen-Sandvik, 2008), social stigma (Goffman, 1963), 'precarity' (Butler, 2009), and insecure selves (Collinson, 2003), has established that organizational employees often regard their work identities as imperilled, menaced, and fragile. Historically, much attention has been paid to the identity threats faced by blue collar workers (Burawoy, 1979; Collinson, 1992), and socially marginalized groups

such as the unemployed (Snow \& Anderson, 1987). Increasingly, scholars have focused on the difficulties that professional workers experience dealing with perceived assaults on their 
desired identities (Gill, 2015; Knights \& Clarke, 2014). These studies have demonstrated that people seek variously to diffuse, neutralize, modify, adapt, deflect, defend against and mitigate identity threats; the removal of threat being the most common supposed objective as, it is contended, '...beneficial consequences emerge from identity threat only when threat responses eliminate threat' (Petriglieri, 2011, p.655). We contribute to these debates by analysing how identity threats are construed subjectively through discourse allowing us to establish that putative 'threats' may constitute a supply which professionals draw on to articulate preferred versions of their selves.

We build our argument through an analysis of how first-team players for Northern Knights ${ }^{\mathrm{i}}$, an English Rugby League football club, constructed and appropriated threats to their identities. In offering this analysis we have been influenced by the emerging tradition of scholarship which has explored organizations through the lens of sport, drawn parallels between the two in terms of their shared concern with competition and cooperation, and detected similarities between elite athletes and high-potential managers (Day et al., 2012). The research contribution we make is threefold. First, we argue that rugby players engaged in two sets of interrelated identity construction processes, 'threat construal' and 'threat response'. We show how they constituted 'threats' to their player identities relating to the shortness of their careers, injury and performance and how these were appropriated through other forms of identity work: focus on the present, tough, self-reliant professionalism, and aspirations for success. Second, this permits us to analyse how rugby players used threats as a resource to author narratives of their desired occupational and masculine identities. Third, this leads to a discussion of how (male) professionals' identity discourse is an assertion of agency framed within relations of power. Our study is important, in part, because, despite 
notable exceptions (Collinson, 1992), there are still relatively few empirical studies that examine insecure identity talk (Ybema et al., 2009, p.312).

\section{Identities in Organizations}

Subjectively construed identities are the meanings that people attach reflexively to themselves in response to questions such as 'who am I?' and 'who do I want to be in the future?' Encoded in multiple and dynamic self-narratives, identities are complex representations of the self that evolve through soliloquy (Athens, 1994) and in interactions with others (Goffman, 1959). As Giddens (1991, p.54) maintains, 'a person's identity is...to be found...in the capacity to keep a particular narrative going' [emphasis in the original]. Narrative identities are authored by individuals and groups from materials and opportunities provided by locally available discourses within which they manoeuvre actively as they engage in identity work. Identity work refers to activities of formation, maintenance, repair and revision by which people seek to realize desired versions of their selves (Sveningsson \& Alvesson, 2003). In line with considerable previous theorising, our focus is on discursive identity work, specifically, those practices of talk by which people, talking as particular kinds of subjects, author self-narratives (e.g., Brown \& Toyoki, 2013; Gagnon \& Collinson, 2014; Knights \& Clarke, 2014). We argue that rugby players drew on identity threats as a resource, and managed them to author occupational and masculine identities which positioned them as elite, focused on the present, tough, self-reliant, professional, and aspirational.

Identity, as Berger and Luckmann (1967, p.195) argue, '...remains unintelligible unless it is located in a world', and our interest is in identity discourses allied with the domain of rugby. Of these, the two most significant for our study are those concerned with professionalism and masculinity. As with other professional workers, rugby players self-define in terms of what 
they do and regard themselves as engaged in prestigious work in which they have appreciable autonomy (Abbott, 1988; Nauright \& Chandler, 1996). Similarly well-attested is that rugby football is '...one of the most masculine of sports - particularly in the British isles', being associated with qualities such as hardiness, endurance, self-sacrifice and fearlessness (Chandler \& Nauright, 1996, p.2; Young, et. al., 1994). There is 'growing recognition of the specific gendering of men in organizations' (Broadbridge \& Hearn, 2008, p.42; Bordo, 1999; Collinson \& Hearn, 1994, 1996; Watson, 2000), and this research has shown that gender is not 'given' but has continually to be sustained through performative (including both bodily and discursive) acts shaped profoundly by both local and cultural scripts (Butler, 1990). Although our prime concern is with discourse, as we note later in our discussion, experiences are embodied, and there is a need for further research which takes embodiment as 'the starting point for analysing human participation in a cultural world' (Csordas, 1993, p.135; Butler 2009; Connell, 1995; Watson, 2000).

Studies have demonstrated that identities are constituted within marshalling yards of power/knowledge and subject to disciplinary processes which not only facilitate but shape and constrain agency (Alvesson \& Willmott, 2002; Fleming \& Spicer, 2003). This is particularly evident in professional sports clubs which have prominent surveillance systems and well-developed disciplinary practices which structure the daily lives of players (Foucault, 1979). Our concern is less with specific processes of disciplinary power and employee resistance, on which there is a substantial literature (Fournier, 1999; Thornborrow \& Brown, 2009) than how rugby players' identity work is itself an expression of agency framed within and suffused by relations of power. We emphasize how, in responding to threat, professionals may be regarded as self-disciplining subjects who produce themselves through technologies of the self as subjects who can be measured, verbalized, judged and 'improved'. People are 
able generally to 'agentially play' (Newton, 1998, p.430) with discursive resources for agency is inherent in the regulation of meaning. Yet the '...state of happiness, purity, wisdom, perfection, or immortality' (Foucault, 1988, p.18) for which people quest is realizable only within frameworks of disciplinary power, even if, as Starkey and McKinlay (1998, p.231) note, these are, to an extent, '...of their own making'.

\section{Identity threats and defensive strategies}

Individuals' and groups' working lives are '...filled with a desire for security’ (Knights \& Willmott, 1999, p.56), but '...the socially constructed nature of identity renders it inherently unstable....and...highly problematic' (Collinson, 1992, p.27). Identities are often precarious and under threat, being subject not only to an '...individual employee's self-doubt and emotional instability' (Gabriel, 1999, p.185) but also the judgements of others and the exigencies of organizational life (Humphreys \& Brown, 2002). For Giddens (1991, p.185) '....in the reflexive project of the self, the narrative of self-identity is inherently fragile', while for Knights and Clarke (2014, p.352) professional identities are increasingly 'insecure'. As Butler (2009) has shown, 'precarity' is an aspect of the human condition, and 'Lives are by definition precarious' (p.25). Drawing on a long-standing sociological literature on identity threat (Durkheim, 1933) recent studies of managers depict them as locked in continuing states of 'profound anxiety' (Jackall, 1988, p.40) and stricken by frailties (Casey, 1995); while workers' lives are portrayed as dominated by permanent, unsettling anxiety (Burawoy, 1979). As Collinson (2003, p.530) asserts, people in organizations are prone to multiple, intersecting insecurities - existential, social, economic and psychological - and this has resulted in identities which are ‘...increasingly precarious, insecure and uncertain'. 
Despite consensus that 'Threats to identity are as ubiquitous as they are unsettling', nevertheless, 'At the most fundamental level, there is a lack of agreement regarding what, exactly, identity threat is' (Petriglieri, 2011, p.641). In our analysis, identity threats are regarded as being construed through identity work: they are any discursively constituted thought or feeling that challenges one of an individual or group's preferred identity narratives. This conception of threat contrasts with that scholarship which has considered threats to identities to be posed by 'objective' factors (Breakwell, 1983), temporally specific events such as bullying (Lutgen-Sandvik, 2008) or particular individual/group characteristics associated with stigma (Goffman, 1963) or dirty work (Ashforth \& Kreiner, 1999). Of course, this is not to deny materiality or that certain threats may have limited scope for (re)interpretation. What a discursive approach highlights is that people can generally choose what threats they talk about and how those threats are talked about in relation to the self. Language is '....a representational technology that actively organizes, constructs and sustains social reality', and our task is to analyse how a particular community of rugby players' discursive practices, that is, practices of talk, came '...to form the instinctively shared calibration points' in matters of self-authorship (Chia \& King, 2001, p.312).

Our approach to the study of 'threat' is sufficiently broad to allow us to focus on the ongoing insecurities about the self that are '... a permanent feature of everyday experience' (Collinson, 2003, p.531). This understanding of the pervasive and continuing nature of threats to identities resonates with a substantial literature on identity regulation which highlights the vulnerable, sometimes frail, generally contested and precarious nature of managers' and other workers' selves in organizations (Clarke, Brown, \& Hope-Hailey, 2009; Fleming \& Spicer, 2003; Gill, 2015). It is by acknowledging the prevalence of identity threat that we can 
investigate in-depth the inherently unstable and ambiguous nature of work identities, and explain how these may be appropriated in processes of identity work.

Research suggests that people respond to identity insecurities and threats either through various forms of identity work (Snow \& Anderson, 1987) and/or reliance on the discursive practices associated with strong occupational and workgroup cultures (Ashforth \& Kreiner, 1999). Collinson (2003) outlines three identity strategies which individuals under threat pursue to survive in surveillance-obsessed organizations: conformist selves who adapt and accommodate to organizational demands, dramaturgical selves, who impression manage the appearance of acceptance, and resistant selves, who employ various ruses for resistance such as irony, satire and cynicism. Gabriel, Gray, \& Goregaokar (2010) illustrate how unemployed former managers engage in three forms of narrative coping - temporary derailment, end of the line, and moratorium - in order to make sense, console and sustain their sense of self. Knights and Clarke (2014) examined how academics react to perceived identity threats by self-defining as imposters who admit to self-doubts, aspirants who work on ideal selves, and existentialists who seek (though may not find) meaning through their work. These and other studies, while valuable, have focused mostly on people's attempts to manage threats rather than the construction of threats per se, and as a result have not analysed specifically how articulations of threats to identity narratives can be important resources for identity work on desired selves.

\section{Research Design}

This inductive, in-depth case study research was conducted between April 2011 and May 2012 at Northern Knights, an English professional 'Super League' (i.e. top division) Rugby League football club. A wealth of research suggesting that 'sport offers an interesting and 
relevant context for organization researchers' (Day et al., 2012, p.398), that professional sports have more in common with work than play (Frey \& Etizen, 1991) and that increasingly 'game structures parallel work structures' (Keidel, 1987, p.591), make a sports club a compelling setting in which to study identity issues. Their work being both high status and physical, and their performance of it unusually visible and subject to the judgement of and often more-or-less immediate feedback from multiple stakeholders - including not just club members but family, friends, fans, and journalists - rugby players represent an 'extreme' case of surveilled elite professional workers. As Flyvbjerg (2006, p.229) notes, ‘...extreme cases often reveal more information' than 'typical' samples and are '... well-suited for getting a point across in an especially dramatic way'. In this instance, our focus on rugby players allows us to highlight processes of identity work concerned with the construal and appropriation of threat that are, perhaps, less palpable in other professional settings.

\section{Context}

In contrast with Rugby Union, UK-based Rugby League and its clubs raise generally less revenue through television rights and sponsorship, have arguably a lower national profile, and are often reliant on their owners for additional finance to keep them solvent ${ }^{\mathrm{ii}}$. Northern Knights was in this respect 'typical', but had the added problems of an antiquated stadium, a relatively small (if fiercely loyal) fan base, and another nearby Super League team that competed for sponsorship, attendance and publicity. The club, which had a lengthy heritage, was owned and managed by a Chairman and a Board of Directors, and employed a staff of approximately 100 people including a squad of 23 'first team' players. The players were a mixture of overseas 'stars', generally from Australia and New Zealand, who were attracted by the relatively high salaries, and local men from the city who had been developed through the organization's academy system. Other employees included coaches, assistant coaches, 
specialists responsible for strength and conditioning, nutrition and sports psychology, and a large number of support and administrative staff such as grounds men, retail personnel, and those who dealt with the media, advertising, finance and community engagement.

\section{Data Collection}

Following initial contact with a senior director of the club, the primary researcher met with other directors over a period of several weeks, with permission for her to study 'what is it like to work at Northern Knights?' granted formally soon after. All the data were collected by the primary researcher, a co-author of this paper, who spent an average of one day a week at the club observing meetings, home matches and training sessions for the players, watching people get on with their jobs on the pitch and in their offices, and chatting informally with staff about themselves, their work, and the organization ${ }^{\mathrm{iii}}$. The main source of data were formal semi-structured interviews with 47 personnel, including all 23 'first team' players, the chairman, 5 directors, and a broad mix of coaching, administrative and support staff. Research participants tend often '...to orient to the research interview by "doing being an obedient research participant", and giving the interviewer what they want to hear' (Speer, 2005 p.194). In response, we conceived our interviews as open 'conversations with a purpose' (Burgess, 1988) and asked interviewees a range of general identity-themed questions about themselves, the club and their profession, such as 'what is important to you in your work?' and 'where do you see yourself going as a rugby player?' ${ }^{\text {iv }}$ This said, we were, nevertheless, continually aware that, as in any interview situation, meanings were being actively assembled by people engaged in processes of impression management (Cassell, 2005). 
While it took a couple of months for the researcher to feel fully comfortable on-site, most of the awkwardness she felt was experienced in the early phase of the project and outside of the interviews, for example while waiting in the social spaces usually reserved for club members. The interviews varied in length from 30 to 120 minutes. All the interviews were audio recorded and fully and professionally transcribed. The transcriptions ranged from 3,000 to 13,000 words yielding a total dataset of approximately 128,000 words. The players, who are our principal concern here, were invited (but in no way compelled) to talk with the primary researcher (whom they referred to as 'the book lady'), and seemed happy to do so simply out of inquisitiveness. The interviews were conducted in an open and relaxed manner, no one refused to answer any question, and many appeared enthusiastic to have the opportunity to talk about themselves. The players' growing comfort with the researcher meant that on several occasions friends of the player being interviewed - who happened to be passing pulled-up chairs and joined in the conversation, apparently curious to join the discussion. It may be that one consequence of this was that the identities co-constructed in these interactions were as much for themselves and one another as for the interviewer. After the initial interviews had been undertaken in the club's plush corporate rooms (designed to accommodate outsiders) the researcher was granted permission to conduct further interviews in the shabbier, but clearly prestigious, rooms designated as being for the staff and players, indicating, she felt, symbolic acceptance of her.

\section{Data analysis}

Grounded on an understanding that language is, arguably, 'the primary medium of social control and power' (Fairclough, 1989, p.3), we analysed how participants sought to create their local worlds, and their identities, through discourse. In line with considerable other research we regarded the identities of interviewees as practical discursive accomplishments, 
co-constructed with the researcher in an interview setting (Brown \& Toyoki, 2013; Down \& Reveley, 2009; Knights \& Clarke, 2014). Our methodological approach is in this respect consistent with Thompson and McHugh (2002, p.354) who argue that:

'Identity work is conscious and unconscious, individual and collective, competitive and collaborative. It is a vehicle of self-expression and enactment, and at the same time binds us to systems of ideological and self-legitimation, through which we accede to systems of control, both internal and external'.

These identities are, of course, local social productions which cannot in any sense be regarded as 'definitive', are dynamic, tensional, and prone (at least potentially) continuously to revision - there is always another story of the self that can be told (Holstein \& Gubrium, 2000, p.70).

The analysis of our transcript and other materials involved fairly standard, systematic, inductive processes in which we circled back-and-forth between data and theory focusing on instances of identity work (Brown, 2015; Coupland \& Brown, 2010). This involved the identification both of explicit identity work ('I am such a talented player') and other instances of talk where identity was clearly at stake ('It's [rugby] all I ever wanted to do'). Concentrating on identifying where participants' talk 'said' something important about them, and using an open coding system with constant comparison, we identified substantial numbers of seemingly significant themes ('pride', 'credibility', 'future thoughts' etc.) which, through iterative processes were collapsed and refined into broader categories (Strauss \& Corbin, 1990). For example, data coded under category headings as seemingly diverse as 'temporality', 'careers', 'contracts', and 'negative stories' came ultimately to be assimilated under the broader thematic category 'short careers'. That is, in response to the open questions we asked, players talked about identity-related issues and experiences which they found difficult, troubling and anxiety-provoking, and also uplifting, reassuring and felicitous, and it 
is from this morass of complicated, interconnected, often ambiguous and occasionally seemingly contradictory talk that our analysis is derived.

Processes of analysis revealed a large amount of data relating to identity threats - the brevity of player careers, injuries, and performance issues - and their management - through focus on the present, talk about tough, self-reliant professionalism, and aspirations for success. An overview of our coding scheme with indicative quotation material is provided in Table 1. Over time, we came to recognize that players were constructing identity threats in order to appropriate them in ways which allowed the men to author preferred occupational and masculine identities. While the term 'appropriation' is used sometimes in the arts to mean the use of objects and images with little transformation, in the social sciences it refers usually to how people 'adapt, combine, and transform' culturally shared discourses (Thompson \& Haytko, 1997, p.18). In the context of identity, Ricoeur (1971) describes 'appropriation' as a form of self-interpretation involving processes of self-contemplation and self-formation in which the self and meanings are contemporaneously constituted. Consonant with both Thompson and Haytko (1997) and Ricoeur (1971) we use 'appropriation' to refer to processes of self-meaning production, and we attend specifically to how rugby players interpreted and made use of discursively constituted 'threats' which they had themselves helped to constitute.

We focused on these threats and forms of response because they featured prominently in our transcript data. Indeed, every player mentioned each of the three threats and three appropriations, indicating that these were not merely 'personalized consumption meanings' (Thompson \& Haytko, 1997, p.35), but rather shared cultural resources. In moving from datagenerated first-order codes to second-order themes we followed a long tradition of 
interpretive research. For example, Boyatzis (1998) describes this as a movement from directly observable (manifest) data codes to a latent level thematic analysis which reveals underlying phenomena, while Van Maanen (1979) refers to it as a stepped process from 'first order' to 'second order' codes. This, of course, involved acts of interpretation, and as with all analyses this implicated us in '...a creative endeavour' (Wagley, 1983, p.16). Accordingly, we do not claim privileged status for our constructions, and instead acknowledge explicitly that 'social science is the practice of a craft' (Mills, 1970, p.15) which involves 'imagination, flair, creativity and an aesthetic sense' (Watson, 1994, p.78). Our position embraces 'a postmodernist climate' where doubt and distrust extends to 'all methods equally' (Richardson \& St. Pierre, 2005, p.961).

Table 1 about here please

There are three important additional points to note here. First, during 2011/12 the club experienced notable staff turnover which in practical terms meant access to Northern Knights had continuously to be renegotiated, and the primary researcher felt herself always to be '...banking on the kindness of strangers' (Van Maanen, 2011, p.221). Second, as has been observed frequently, qualitative research of this type is 'always shaped by the researcher's own personal values...political and moral principles' (Bell, 1999, p.17), in which the ethnographic self is caught-up 'to some degree' (Cant \& Sharma, 1998, p.10). This article is, thus, a form of 'textual collusion' (Fuller \& Lee, 1997) in which we, our reviewers, editors and readers, are all engaged in relations of power (Humphreys, Brown, \& Hatch, 2003). Third, we were keenly aware that the primary researcher was a female in a largely male organization and that there was consequently little scope for her to blend into the background or to be mistaken for an employee. Much has been written about the often deep-seated 
inequalities in ethnographic relations between researchers and informants especially as they impinge on issues of gender (Callaway, 1992). This said, we note that it is always the case that researchers, both male and female, '...produce and reproduce our [and others] gendered lives...within our phenomenological experiences' (Pullen, 2007, p.318), and it would be incorrect to over-attribute significance to this aspect of our research design. The resources at our disposal, including the gender of the researcher, have led us to a particular - not definitive - understanding of our research subjects, though one that we hope is plausible and generative.

\section{Threatened Identities and Appropriation Strategies}

In this section, we establish first that rugby players cherished their identities as professional rugby players. We then consider three specific threats to these identities (short careers, injury, and performance issues) and three appropriation strategies by which players managed them (focus on the present, tough, self-reliant professionalism, and aspirational goals) to author desired occupational and masculine identities. We present the 'threats' and 'appropriation strategies' in matched pairs. We adopted this representational strategy partly for ease of communication, but also because players relied most heavily on one specific appropriation strategy when dealing with each threat. This said, the overall picture was more complicated, and each of the appropriation strategies was, we contend, significant in players' management of multiple threats, a theme to which we return in the discussion.

\section{Cherished Threatened Rugby Identities}

Work is generally a significant aspect of employed individuals' lives which provides them with discursive resources from which they (re)author continuously versions of their selves. As Butler (1998, p.70) asserts: 'Every man's work...is always a portrait of himself'. Like those Amway employees who 'loved' their job as distributors (Pratt, 2000) and aspirant elite 
soldiers who crave authentic identities as paratroopers (Thornborrow \& Brown, 2009), rugby players said that they delighted in their work because it was an expression of their preferred selves:

'I started playing rugby when I was four...so I always wanted to be, and, you know, be a rugby league star, that was my dream as a kid' (Player \#16).

Players said that they had generally been involved with rugby from an early age, commented on the hard work and good fortune it had taken to succeed, and described being a professional rugby player as their ideal job:

'...I started playing when I was three or four years old, so it was always part of my life...probably the only thing born to do, never really had any aspirations to be anything else, other than footballer...I've never really worked a proper job' (Player \#17).

Players spoke most eloquently about their commitment to the sport of rugby and the 'selfsatisfaction' (Player \#5) they gained from being professional rugby players:

'I don't ever call it a job, because, you know, it's, it's a great way to earn a living because you're...doing something you love and you're getting paid for it' (Player \#12).

Rugby, the men said, had given them opportunities to cultivate what they considered to be privileged selves as professional sportspeople. Concomitantly, they recognized that being a professional rugby player required commitment to a regime which not only enabled them to author desired identities but imposed considerable restraints:

'...you're rugby league players 24 hours a day and, you know, what we eat, what we do, you know, how we drink, how much we sleep, everything's all controlled' (Player \#7).

Overwhelmingly they recognized that '...my best skill was rugby so I put all my effort into that' (Player \#20), and so 'I couldn't see myself doing anything else now' (Player \#19).

Threat: short careers. The players stated that their playing careers were likely to be relatively brief and that even the most talented and fortunate individuals could expect to play only for around fifteen seasons before retiring at the age of approximately thirty two ${ }^{\mathrm{v}}$ : ‘...it's only a short career' (Player \#9). 
‘...because obviously rugby's like short, it's a, only a short career type thing' (Player \#10).

While they were generally on contracts of employment of between one and five years, these could be terminated by the club at any time. Rule changes which meant that clubs could from the next season only field four overseas players meant that Northern Knights was in the process of shedding nine men from the squad:

'...it's just cut-throat because even if you're a five years' deal, that doesn't mean anything these days' (Player \#17).

‘...clubs aren't ...loyal [to individual players] anymore, like they used to be' (Player \#22).

Concerns about the brevity of their rugby playing careers were bolstered by melancholic stories of those who had failed to prosper having retired from the game:

'I've heard of in the past very successful professional rugby league players having amazing careers and then...end up being like a taxi driver' (Player \#3).

'...what's happened to some players that have like retired in the past when they've gone into depression and gambling problems because they've gone from one day being a full-time professional - retiring and they've got nothing' (Player \#9).

That the men experienced the shortness of their playing careers as threatening to their preferred identities as rugby players was indicated by the anxieties that they occasionally expressed about their own futures:

'Worse case scenario would be if I got sacked tomorrow and had to go home, couldn't play again... you know, ride it as long as I can' (Player \#16).

'...that's [short career] quite scary for a lot of players...' (Player \#2).

Appropriation: focus on the present. Overwhelmingly, players were hesitant to talk at length or in detail about the brevity of their playing careers, mitigating this threat by focusing on the immediate present. Younger players said that they postponed thinking about such matters:

'I'm not really as old as these guys yet, so I'm still quite young and just want to, just a young kid trying to make it at footy really. So I guess I'll start thinking about that stuff [the future] when I get older' (Player \#8).

'I'm hoping to be playing rugby league at a high standard until I'm 32, that's my goal... when I get to that age, I'll, you know, reassess my options' (Player \#4). 
Even those coming toward the end of their professional careers said that they had engaged in little forward planning:

'[I’ve]...still not worked out in my head what I'm going to do when I finish' (Player \#3).

'I've got one more year...if I'm still performing and they want to keep me, then we'll talk, but if not then, yeah, we'll just see' (Player \#5).

The players' union provided some educational options - relating to building work, plumbing and even the law - but few individuals claimed to have studied for anything other than basic gym instructor certificates, and when pushed most talked vaguely about a long-term future in rugby either as a trainer or a coach:

'I see myself...maybe coaching' (Player \#2).

'[I'd like] to do like some gym instructor course...so if I gets to a point where the team sack me off then I've got something to fall back on type thing' (Player \#10).

Our interpretation of this identity work is that the men constructed their careers as relatively brief and then appropriated the threat this posed in ways which positioned them as being fully committed to their occupation and as conforming to a locally prevalent masculine script. Players' insistence that they were wholeheartedly focused on the 'now', and their reticence to talk about their long-term, post-rugby careers was a strategy that helped to maintain their positive rugby-occupational identity narratives. It was both an exclusionary and immersive discursive practice that bolstered their occupational identities by minimizing and marginalizing talk about other forms of work, and confirmed their total commitment - what Wacquant (1995, p.507) refers to as 'obsessive devotion' - to being a rugby player. This analysis resonates with Collinson's (1992, p.30-31) observations on shop floor workers that in attempting ' ...to secure stable definitions of identity' some information '... is forgotten or ignored' in self-defeating processes of 'denial'. Players' disavowals of concern with longterm post-rugby thinking resonated with a hyper-masculine script in which men are supposed to be un-self-reflexive and to focus on the job-in-hand (Pringle, 2001, p.426). Unwillingness 
to talk about the end of their rugby careers helped players to manage their anxieties by positioning them as men who were focused, and 'in control' of their careers, but may also have had negative long-term implications, as it dissuaded them from retirement planning.

Threat: injury. The men talked about the threat to their rugby player identities posed by injuries which could sometimes prevent them from playing (i.e. physically enacting their desired selves) and which potentially might terminate their playing careers ${ }^{\mathrm{vi}}$ :

'...it's just, unfortunately it's part of the game when you play a contact sport: carry on and you're going to get hurt' (Player \#22).

'I could play for another, you know, three years, maybe more: but then, I could finish tomorrow' (Player \#2).

Many players commented on their past or current injuries that had or were currently impeding their ability to continue in the profession:

'I actually got injured in the pre-season's training, so I haven't played a game yet' (Player \#20).

'...I was out for like two years with a back injury... and that was a big thing in my career because I didn't play for two years...I've been really unlucky with injuries, I've been out for like nearly three and a half, four years. I'm injured now and broke my leg like eight weeks ago' (Player \#19).

The omnipresent threat to players posed by injury was echoed by Coach \#3 and Coach \#4, both of whose playing careers had been terminated prematurely by injuries:

'...had a fantastic time, really enjoyed it, and from there obviously pretty bad dislocated shoulder, and it was time to get me to go' (Coach \#3).

'I put all my eggs in one basket, wanted to become a professional rugby player...several operations later, you know, I've come to the end' (Coach \#4).

These personal reflections were supplemented by tales of other talented players they had known who had been forced to retire early as a result of injury:

'...a winger back home, he just did his ankle in the game...he was up-and-coming, played for New Zealand...they just couldn't ever get the ankle right, after four or five surgeries just kept trying to cut back but the bone was just dying, so he had to retire' (Player \#13). 
The anxieties the players associated with injuries were indicated by their descriptions of them as 'frustrating' (Player \#20) and 'unfortunate' (Player \#22) and the discomfort they evidently associated with the potential for being out of the game:

'I don't think you really speak about, you don't think about getting injured...[but]...when you see somebody does get a bad injury you think "oh imagine if I got, that happened to me like"" (Player \#18).

Appropriation: tough, self-reliant professionalism. One means of managing the threats posed by knowledge that they were participating in an injury-prone career was a discourse of tough, self-reliant professionalism. Rugby, they said, was '...a tough sport' and players '...think they've got to be tough guys' (Player \#17). The players maintained that there was a 'work hard/play hard' culture, which meant that 'you train hard' (Player \#6), and that:

'...even if you're not best friends that you're working hard for each other at training every day and you, and you work hard for each other on the field'.

Coach \#6 remarked that 'you're in a large group of boys, it's not really a done thing to be soft', while Coach \#3 talked of the need for 'tough geezers', for men to be naturally aggressive, and the near-impossibility of simulating or fabricating the 'right' mentality:

'...it's very difficult to put the dog inside somebody no matter how hard you train them, you know... you can't make him tough'.

One aspect of this was a discourse of self-reliance or self-sufficiency (referring to the reliance on one's own powers, resources and independence):

'... at the end of the day, the only one that can hold yourself back is yourself. If you really want it then you can do it' (Player \#8).

'You [referring to players], you have, you have to be self-sufficient' (Coach \#1).

Another element of this talk centred on 'professionalism'. There was a broad consensus that theirs was a profession, and considerable deference was paid to those players deemed to be model professionals who dealt 'appropriately' with the on-going pressures and inevitable setbacks associated with being a sportsman: 
'I think everyone knows now it's a profession' (Player \#18).

'...he's [a player] played at a high level for a long time, you know, he turns up week in week out, you know, he's professional' (Player \#2).

Arguably, talk about injury and the prospect of being injured construed for players what Giddens (1991) refers to as 'fateful moments' which threatened the 'protective cocoon' that maintained their quotidian 'ontological security', and which required identity work to fashion (successful) narrative continuity. On this reading, the players' talk about being tough, selfreliant and professional countered threat by positioning them as knowingly aware of the occupational risks they faced and able effectively to deal with them, even if this meant merely accepting stoically the 'realities' of their chosen sport:

'I've had different injuries...it's just, it's your job... it's just something you've got to deal with' (Player \#23).

This finding supports other studies which have shown that elite professional sportsmen may counter identity threat through talk about acceptance of risk, and by seeking to normalize injury (Young, et. al., 1994). Such talk was also a discursive performance of players' masculinity. Injuries are symbolically threatening in part because they deprive a man of his (self-validating) ability to play and are thus (at least temporarily) emasculating. While injuries could not be ignored - they were too salient for this - talk about them provided the men with opportunities to reaffirm their masculinity by emphasizing that they were willing to make sacrifices (put their bodies on the line) for a cause they were committed to (the team/club). As has been observed, representing oneself as 'tough' and 'hard' is particularly important in heavy contact sports such as rugby because aggression is integral to the masculinity scripts that dominate locally in these regimes, and is generally lauded and 'highly valued' (Pringle, 2001, p.428). Moreover, talk about self-reliant, stoical professionalism was a fortifying assertion of an independent masculinity that, to an extent, ameliorated the threat posed by explicit recognition of physical vulnerabilities and frailties and the knowledge that 
they were all replaceable, an anxiety which often '...bites deep into individual assuredness' (Collinson, 1992, p.175).

Threat: performance issues. Players were under continuous pressure, they said, to perform at a high level: '...you've got to be best at your job all the time' (Player \#6); and there was intense competition among the 23 first-team players for selection:

'...the only rivalry really is, is in the competition for your place' (Player \#3).

'...there's no like, no way about it, everyone wants to play and then one of my best mates [is] in my position, and I, I'd want to play over him all the time' (Player \#16).

Established, senior players could still recall the angst associated with not being selected to play, and spoke of the relief of being consistently on the team, while the younger players talked of wanting to 'prove myself at this level' (Player \#6):

'...it's relieving that I'm actually, you know, able, I've cemented a spot over here in the team at the moment' (Player \#16).

Not being selected was anxiety provoking, symptomizing the relative powerlessness of players and the considerable disciplinary power exercised by the coaching staff, which for some, was a spur for personal reflection:

'... it has upset me a bit, but I can't really let that get me down because I, I haven't been performing...so I've just kind of got to accept it...I've just got to kind of just get on with it' (Player \#10).

'...if he [the coach] feels that they're [other players] fit to play in front of you, then you're just going to have to handle it and you can't take it out on the people that are playing front of you, you've just got to just try and work hard and get back' (Player \#4).

Threat attached to performance issues meant, the men said, that they constantly selfmonitored and evaluated their selves in order to seek improvement:

'...you've got to look at yourself: are you playing well? Is there someone playing better than me... (Player \#13).

One explanation for these performance anxieties is that not being chosen to play rendered an individual a kind of 'marginal man' (Stonequist, 1937) who did not fully 'belong' to the 
group he keenly identified with. This can cast men into a liminal state which may be experienced as an uncomfortable combination of 'ambiguity and in-between-ness' (Beech, 2011, p.288). The players' comments echo Kerkhoff and McCormick's (1955, p.52) description of the consequences of marginality, which include being plagued by doubts, selfconsciousness, fearfulness, hypersensitivity and '... a restless feeling that gnaws at him'. They resonate too with other research which suggests that people at work are often troubled by the sense that they are, or are open to accusations, that they are fake, false, inauthentic or even fraudulent (Costas \& Fleming, 2009).

Players and coaches spoke also of the anxieties posed by the team's inconsistent performance which meant that '...this year's been a bit difficult, you know, and that's where, like I said it's, you know, it's frustrating' (Player \#2). Pressure to perform was said to come not just from the fans who '...want their football side to win and they're pretty passionate about it' (Coach \#2) but also from the Chairman who '...has regular meetings with the whole squad' (Player \#3), was '... always in the changing rooms, kicking round after a game' (Player \#19) and '...expects things to be done on the field' (Player \#18). As this research was being conducted it was clear that many players' expectations were not being met in terms of results: '...obviously we're disappointed with this season so far; but we've still got four games left to prove ourself' (Player \#6).

Appropriation: aspirations for success. Performance-based threats to individuals' identities were appropriated by players (and also coaches and administrators) through talk about their desire for success. Players maintained that '...we want to do the best' (Player \#16) and that ‘we want to win' (Player \#6):

'....all I think about is winning and that's it...I'd definitely like to be a one club player...be a big influence at this place and hopefully, you know, sort of leave a, a bit of a legacy there for myself that I can be proud of' (Player \#16).

'... our attitude is more of a, a killer attitude and a hunger to succeed and win and, win at all costs' (Player \#2). 
Most talk centred on winning trophies:

'Well hopefully in five years' time, I've won something here at the club, that's my goal before I leave, I want to win something at the club and bring some silverware in Super League' (Player \#18).

These sentiments were expressed also by other club members. Coach \#1 said that 'I have a burning desire to win trophies' while Director \#1 insisted that: 'I've got to finish the job, which means winning something somewhere down the line'. Most agreed that the team and the club were on an upward trajectory:

'I think, you know, we're heading in the right direction and we're going somewhere in the next couple of years' (Player \#15).

'...they [Northern Knights] went from second last to seventh to fourth, to reaching the semis to six...I'm still really proud of where the club's got to' (Player \#2).

Talk about what had been achieved so far and what was possible in the future may have served as a deflection tactic that diverted attention from problematic issues (in particular their recent lack of trophies) and reinforced the men's commitment to (successful) occupational rugby identities. Such comments are aligned with what Thornborrow and Brown (2009) refer to as an aspirational identity narrative which harnesses societal injunctions to be 'successful' and to 'achieve', and sustains the fantasy that permanent, substantial selves can be realized. The need for achievement was evidently integral to local masculinity scripts just as it is in Western society more generally (Collinson, 1992) and explicit commitment to 'winning' was seemingly a non-negotiable aspect of rugby manhood. Our findings thus support other commentators who have suggested that in contemporary rugby 'The paradigm of the Darwinist warrior is still dominant and the cry is not "beware" but "aspire" (Mangan, 1996, p.154). Like other male aspirants aiming permanently to secure their status - be they trainee soldiers, accountants or managers - rugby players desired to tell a heroic coming of age tale that would make them men, which in this instance meant winning silverware. 


\section{Discussion}

We have analysed how elite professional rugby players engaged in discursive identity work in which they construed threats to their work identities that they appropriated to fashion preferred occupational and masculine selves. In this discussion we first reconsider the contribution we have made to the theorization of threats as opportunities for identity work. Second, we analyse players' identity work as an expression of agency but also as an effect of disciplinary practices and technologies of the self. Third, identity threat is discussed in relation to issues of embodiment and masculinity. Finally, how this study may be generative, and its limitations, are addressed before we draw some brief conclusions.

\section{Identity work, threats and defensive strategies}

The key contribution to theory we have made is to argue that through discursive identity work elite professionals construe identity threats which they employ opportunistically to author preferred occupational and specifically masculine identities. Our position resonates with other sociological theorising on insecure, anxious, fragile and resistant selves (Collinson, 1992, 2003; Knights \& Clarke, 2014), which we have complemented by demonstrating the importance of the construal of 'threats' as a resource for identity work. Threats are not merely rebutted, ameliorated or neutralized, but also a valuable means for constructing desired identities. From this perspective, identities are reasonably regarded not as responses to threat but as constituted by them. Threats, we have shown, are (in part) linguistic inventions (not just) discoveries (cf. Berger \& Luckman, 1967; Chia \& King, 2001; Grant, et. al. 2004), something which is best appreciated by considering what rugby players chose not to mention. For example, rugby players could have chosen - but did not - to talk about the environmental threats (such as the dominance of the rival rugby union code), threats to their rugby identities posed by unsupportive family members, or threats posed by 
existential angsts (self-doubts, intra-psychic conflicts etc.). Similarly, in terms of their appropriation of threats, rugby players could have (but did not) engage in other available rhetorical strategies for identity authorship: they did not blame other people, institutions, or events for their misfortunes, and they did not indulge in any self-recrimination ('if only I had not done that').

Empirically, the principal contribution we have made is to identify the discursively constituted threats and appropriation strategies employed by a group of elite professionals in their identity work. This identity work was (and is likely always to be) messy, fluid, socially negotiated, to some extent individual-specific and nuanced. The representational strategy we have adopted which matches 'brief careers' with 'focus on the present', 'injury' with 'tough, self-reliant professionalism' and 'performance anxieties' with 'aspirational goals', while it captures the key salient themes in our data, is also a convenient simplification. The players' discursive construal of threats and their appropriative strategies were often interleaved and frequently overlapping. The point here is that individuals do not just tell a single, coherent identity narrative. Processes of identity construction are fluid and dynamic: while we may be spurred by narcissistic preoccupations with establishing a secure, stable identity, identities are never 'finished' but continuously worked on in soliloquy and in conversations with others. As Czarniawska (1997, p.49) states, identity is 'a...continuous process of narration where both the narrator and the audience are involved in formulating, editing, applauding, and refusing various elements of the ever-produced narrative'.

\section{Identity work and power}

Elite, professional rugby players possessed some scope to author versions of their identities in which they appropriated successfully a series of self-construed threats. However, identity 
work is not just an expression of agency and identities are also effects of power (Foucault, 1979). Most obviously, players were subject to externally imposed disciplinary processes monitoring, surveillance, hierarchical observations, and normalizing judgements of coaches which informed what for the men was the most significant decision: whether or not they were selected to play for the 'first team'. Players were subject also to technologies of the self such that they monitored continuously their dietary intake, circadian rhythms, and performances in the gymnasium, on the training ground and on the pitch (Foucault, 1979). These were practices of power that produced them as subjects, much like other studies have shown similar processes to shape the identities of 'professionals' such as accountants (Grey, 1994), lawyers (Brown \& Lewis, 2011) and management consultants (Gill, 2015). Further, it was evident that players' efforts to assuage threats to their identities by defining themselves as focused on the present, tough, self-reliant, professional and trophy-fixated, served organizationally important goals. That is, conformance with the club's disciplinary regime was the necessary price that the men paid to realize their desire to be professional rugby players.

Players' discursive construction of their selves constituted them as self-disciplining subjects who articulated identities in terms made available to them by disciplinary practices. Their descriptions of threats and their responses to them were technologies of the self in which they examined themselves and avowed (apparently) uncritically subject positions made available to them by their organization - and the broader community of rugby - as their own. These aspirational identities (Thornborrow \& Brown, 2009) were a means by which players were tamed, rendered docile and obedient, processes referred to by Foucault as 'dressage'. Rugby players' subordination to these narrow, idealized - and for many elusive - identities fed feelings of insecurity, rendered them vulnerable to the critical gaze of others (especially other 
players and coaches), and required them to work ever harder to secure both self-satisfaction and the support of significant others. Players' discursive identity work constituted one aspect of what Foucault terms a 'discursive formation', a seemingly natural apparatus for attributing meaning to a local world, and which enforces consent to arbitrary institutional injunctions. In this instance, individuals' understandings of what it meant to be a rugby player and the means by which they were fabricated by the club formed a relatively tight system of discursive constraint.

\section{Identity work, embodiment and masculinity}

While our analysis has focused on discourse, we note also that in their professional activities it was players' bodies that were on the line, and that gender is a social practice that refers to the activities of bodies (Butler, 2009; Connell, 1995; Csordas, 1993). Recognition that the body is '...the immediate terrain for the ebb and flow of social forces' (Watson, 2000, p.57) is generative in terms of our understanding of threat/vulnerability, masculinity and power. First, threats attach not just to identity narratives but to men's bodies. As Butler (2009) asserts, the body is 'vulnerable by definition' (p.33), indeed 'there are no invulnerable bodies' (p.34), which are not just prone to injury but dependent 'upon social conditions and institutions in order to "be" (p.33). Second, an important element of the masculine identity project of players concerned work on their bodies, these on-going processes of musclebuilding, strength-improving, lung capacity training etc. being conducted within multiple club structures and under the disciplinary gaze of specialist fitness trainers and coaches. Third, the body as well as discourse is a site in which intersect relations of power: 'The body is also directly involved in a political field; power relations have an immediate hold on it; they invest it, mark it, torture it, force it to carry out tasks, to perform ceremonies, to emit signs' (Foucault, 1979, p.25). In short, while players cast themselves as agentic characters in 
their life stories, power produces bodily realities, and '...seeps into the very grain of individuals' (Foucault, 1979, p.28).

Discourses relating to masculinities are central - yet often invisible - in organizing processes and are constructed, maintained and reproduced through language, activities and micropractices (Collinson \& Hearn, 1996). This was true in our case, with sport '...a primary masculinity-validating experience' (Dubbert, 1979, p.164) and a male professional sports team that was an extended boys' club (Taylor, 1995) held together by 'homosocial practices' that perpetuated hegemonic masculinity, suppressed subordinate masculinities and reproduced a pecking order among men (Broadbridge \& Hearn, 2008, p.44). Yet, while players fashioned traditionally 'masculine' identities they were largely compliant (e.g. in their interactions with coaches and trainers), and accepting (not just of on-field instructions but of how to lead their off-field lives). The contradictory demands of a dominant masculine script that prescribed players ought to be independent, tough and self-reliant and institutional requirements which infantilized them by insisting that they follow strict orders regarding when to eat, sleep, train, and play, may in part explain their '...enduring sense of subjective insecurity' (Barrett, 2001, p. 97). This finding resonates also with other suggestions that what it means to be a man does not have a simple, coherent meaning but is, rather, 'an umbrella term encompassing a variety of overlapping perspectives' (Watson, 2000, p.35; Collinson, 1992; Kerfoot \& Knights, 1998).

The identity story the men desired to be able to tell was of how they had - through focus, hard work, self-reliance, toughness and professionalism - overcome multiple threats in an epic quest to play top-tier rugby and win trophies. This narrative was not just about achieving occupational success but of self-transformation, to become a man. Threats - the brief time 
they had to achieve their goals, injuries, and the possibility that they may never or only briefly perform to the required standard - were integral to this narrative, providing opportunities for them to 'prove' themselves worthy. And yet always injuries and negative performance evaluations by coaches were symbolically emasculating, while recognition that rugby careers were strictly time-limited suggested that they were little more than replaceable commodities. That it was, nevertheless, an identity narrative cherished by rugby players symptomizes the importance they attached to a version of masculinity that demanded ‘constant performance from men' (Bordo, 1999, p.34), valorised risk taking (Watson, 2000), and insisted on '.... an overriding commitment to work' involving expertise, commitment, wholehearted identification, obligation and self-discipline (Tolson, 1977, p.81).

\section{Limitations and further research}

This study, like all research projects, has a number of limitations that suggest the need for further research. Our methods are not neutral tools, but are 'ideological' in the sense that they do not merely 'reproduce' but 'produce meaning, and serve to construct 'a particular picture of humans' at work (Tseelon, 1991, p.313). Other readings of these data are also possible, and our concern with work identities needs to be understood against the backdrop that rugby players talked, albeit fleetingly, also about a range of other non-work issues that do not feature in this paper, notably their families. Moreover, our findings have doubtless a number of unique elements associated with the study of what we recognize is an extreme case - an all-male, relatively youthful cohort in a high-surveillance sports context. This begs the question: do the identity narrativizations of other elite professions (e.g., surgeons, lawyers, management consultants), or indeed organizational workers generally, feature the construal of anxiety-provoking threats and appropriation strategies? Our analysis suggests that threats to rugby players' identities led to forms of narrative coping that included nothing more extreme than 'temporary derailment' (Gabriel, et al., 2010): rugby players said that they experienced 
disappointment but rarely mentioned more extreme reactions such as anger, despair, fear or depression. But what happens when a positive identity narrative cannot be constructed, and what implication(s) does this have not just for the individuals themselves but also their work groups and organizations?

While our analysis has focused on the identity work of elite professionals themselves, other research might usefully consider how their occupational and masculine identities are constituted by and in relation to others, such as close friends. There is also a need for further research focused specifically on bodily materiality, on how 'specific social worlds invest, shape, and deploy human bodies' (Wacquant, 1995, p.65) and what Watson (2000) describes as the visceral, experiential, pragmatic and normative forms of embodiment. This project took place over just thirteen months, and other, longitudinal research, is required to investigate how identity threats and appropriation strategies evolve over longer periods of time. Our study has been of a cohort of men who were heavily surveilled and who undertook bodily-dependent work (Cunliffe \& Coupland, 2012); other research on the threats and appropriation strategies of female professionals, perhaps in weak surveillance contexts and where body work is less important, may highlight different threat/appropriation strategies which have different consequences. In short, we anticipate that our analysis may be the spur to considerable further research that explores in more fine-grained ways relationships between threats, appropriation strategies and desired selves.

\section{Conclusions}

In this paper, we have argued that identity threats may be used by embedded actors to author preferred versions of their selves. We have shown how a group of elite professionals concomitantly discursively constructed and appropriated threats to their work identities in a 
continuing quest to author desired self-narratives within a system of disciplinary power. Our research complements other studies sensitive to actor reflexivity and which have found often that workers crafted 'imaginaries' - workable fantasies of unique and coherent selves - may be endangered constructions in need of succour (Harding, 2007). We have shown also that although multiple insecurities may 'intersect and operate simultaneously' (Collinson, 2003, p.529), and that even hegemonic masculinities are tensional and vulnerable, these need not necessarily result in 'debilitating self-doubt' (Sennett \& Cobb, 1977, p.531; Knights \& Clarke, 2014). Identity threats are also opportunities. Ultimately, the search for a treasured, secure, stable, pristine self may be an imaginary, illusory goal associated with obsessional narcissistic preoccupations and symbolic ambitions; and yet its pursuit is individually and collectively utilitarian as it is these processes of identity work that sustain narratives of the self which in turn promote goal-directed action, coherence, and liveability. 


\section{Table 1}

\section{Coding Scheme: discursive threats and appropriative strategies}

\begin{tabular}{|c|c|}
\hline Threats & Appropriations \\
\hline $\begin{array}{l}\text { Short Careers } \\
\text { '...'...you've only got a short time in the game' } \\
\text { (Player \#18) }\end{array}$ & $\begin{array}{l}\text { Focus on the Present } \\
\text { 'I think if you ask most rugby players of my age } \\
\text { now, 25, who've probably got } 5,6 \text { years left, } 7 \\
\text { years at most, I bet if you ask half of them at } 25 \\
\text { year old, they won't know what they, what they } \\
\text { want to do after' (Player \#6) }\end{array}$ \\
\hline $\begin{array}{l}\text { Injury } \\
\text { 'I think there wouldn't be too many players that } \\
\text { play these days that don't have injuries or have } \\
\text { had injuries. It's probably been about since I was } \\
\text { sixteen or seventeen I haven't woken up feeling } \\
\text { fully, fully fine... so it's kind of part of the } \\
\text { game' (Player \#17) }\end{array}$ & $\begin{array}{l}\text { Tough, Self-reliant Professionalism } \\
\text { '...I...try to look after it [body] as much as I can, } \\
\text { because like...your body's your tools at the end } \\
\text { of the day when you're playing this game, you } \\
\text { know, mechanic doesn't go to work without his } \\
\text { spanners would he?' (Player \#12) } \\
\text { '...it makes you work harder as well, you can't } \\
\text { be in your comfort zone' (Player \#19) }\end{array}$ \\
\hline $\begin{array}{l}\text { Performance Issues } \\
\text { 'Well, it's [not being selected to play] } \\
\text { disappointing, that's you know, certainly it's a } \\
\text { difficult thing to come to terms with' (Player } \\
\# 16 \text { ) }\end{array}$ & $\begin{array}{l}\text { Aspirations for Success } \\
\text { 'I wouldn't mind playing [in] Australia...it's } \\
\text { seen as the best league in the world and. } \\
\text { Whenever you do something you always want to } \\
\text { be the best at it, playing against the best...there's } \\
\text { no bigger one that representing your country } \\
\text { really. So I'm hopefully representing England at } \\
\text { some point and playing at the highest standard' } \\
\text { (Player \#9). } \\
\text { 'I'm brought up with the culture you do anything } \\
\text { to win' (Coach \#5). }\end{array}$ \\
\hline
\end{tabular}




\section{References}

Abbott, A. (1988). The system of professions: An essay on the division of expert labor. Chicago: University of Chicago Press.

Alvesson, M., \& Willmott, H. (2002). Identity regulation as organizational control: Producing the appropriate individual. Journal of management studies, 39, 619-644.

Ashforth, B.E., \& Kreiner, G.E. (1999). "How can you do it?" Dirty work and the challenge of constructing a positive identity. Academy of Management Review, 24, 413-434.

Athens, L. (1994). The self as soliloquy. The Sociological Quarterly, 35, 521-532.

Barrett, F.J. (2001). The organizational construction of hegemonic masculinity: The case of the U.S. Navy. In S.M. Whitehead \& F.J. Barrett (Eds.), The masculinities reader (pp.77-99). Cambridge: Polity Press.

Beech, N. (2011). Liminality and the practices of identity reconstruction. Human Relations, 64, 285-302.

Bell, E. (1999). The negotiation of a working role in organizational ethnography. International Journal of Social Research Methodology, 2, 17-37.

Berger, P., \& Luckmann, T. (1967). The Social Construction of Reality: A Treatise in the Sociology of Knowledge. London: Penguin.

Bordo, S. (1999). The male body. New York: Farrar, Straus and Giroux.

Boyatzis, R.E. (1998). Transforming qualitative information: Thematic analysis and code development. Thousand Oaks, CA: Sage.

Breakwell, G.M. (1983). Formulations and searches. In G.M. Breakwell (Ed.), Threatened identities (pp.3-26). Chichester: John Wiley \& Sons.

Broadbridge, A., \& Hearn, J. (2008). Gender and management: new directions in research and continuing patterns in practice. British Journal of Management, 19(s1), S38-S49.

Brown, A.D. 2015. Identities and identity work in organizations. International Journal of Management Reviews, 17, 20-40.

Brown, A. D., \& Lewis, M. A. (2011). Identities, discipline and routines. Organization Studies, 32, 871-895.

Brown, A.D. \& Toyoki, S. (2013). Identity work and legitimacy. Organization Studies, 34, 875-896.

Burawoy, M. (1979). Manufacturing consent, changes in the labor process under monopoly capitalism. Chicago: University of Chicago Press.

Burgess, R. (1988). Conversations with a purpose: the ethnographic interview in educational research. Studies in qualitative methodology, 1, 137-155. 
Butler, J. (1990). Gender trouble: Feminism and the subversion of identity. New York: Routledge.

Butler, J. (2009). Frames of war: When is life grievable? London: Verso.

Butler, S. (1998). The way of all flesh. New York: Random House.

Callaway, H. (1992). Ethnography and experience: Gender implications in fieldwork and texts. In J. Okely \& Callaway, H. (Eds.), Anthropology and autobiography. London: Routledge.

Cant, S., \& Sharma, U. (1998). Reflexivity, ethnography and the professions (complementary medicine) watching you watching me watching you (and writing about both of us). Sociological Review, 46, 244-264.

Casey C. (1995). Work, self and society. London: Routledge.

Cassell, C. (2005). Creating the interviewer: identity work in the management research process. Qualitative Research, 5, 167-179.

Chandler, T.J.L., \& Nauright, J. (1996). Introduction: Rugby, manhood and identity. In J. Nauright \& T.J.L. Chandler (Eds.), Making men, rugby and masculine identity (pp.1-12). London: Routledge.

Chia, R., \& King, I.W. (2001). The Language of Organization Theory. In R. Westwood, and S. Linstead (Eds.), The Language of Organization (pp.310-328). London: Sage.

Clarke, C., Brown, A.D., \& Hope-Hailey, V. (2009). Working identities? Antagonistic discursive resources and managerial identity. Human Relations, 62, 323-352.

Collinson, D.L. (1992). Managing the shopfloor, subjectivity, masculinity and workplace culture. Berlin: Walter de Gruyter.

Collinson, D. (2003). Identities and insecurities: Selves at work. Organization 10, 527-547.

Collinson, D., \& Hearn, J. (1994). Naming men as men: implications for work, organization and management. Gender, Work \& Organization, 1, 2-22.

Collinson, D., \& Hearn, J. (Eds.) (1996) Men as managers, managers as men: Critical perspectives on men, masculinities and managements. London: Sage.

Connell, R. 1995. Masculinities. Oxford: Polity Press.

Costas, J., \& Fleming, P. (2009). Beyond dis-identification: A discursive approach to selfalienation in contemporary organizations. Human Relations, 62, 353-378.

Coupland, C., \& Brown, A. D. (2010). Special Issue on Identities in Organizations: processes and outcomes. Scandinavian Journal of Management, 26, 104-105.

Csordas, T.J. (1993). Embodiment as a paradigm for anthropology. Ethos, 18, 5-47. 
Cunliffe, A., \& Coupland, C. (2012). From hero to villain to hero: Making experience sensible through embodied narrative sensemaking. Human Relations, 65, 63-88.

Czarniawska, B. (1997). Narrating the organization: Dramas of institutional identity. Chicago: University of Chicago Press.

Day, D.V., Gordon, S., \& Fin, C. (2012). The sporting life: Exploring organizations through the lens of sport. The Academy of Management Annals, 6, 397-433.

Down, S., \& Reveley, J. (2009). Between narration and interaction: Situating first-line supervisor identity work. Human Relations, 62, 379-401.

Dubbert, J.L. (1979). A man's place: Masculinity in transition. Englewood Clifs, NJ: Prentice Hall.

Durkheim, E. (1933). The division of labor society. New York: Macmillan.

Fairclough, N. (1989). Language and Power. London: Longman.

Fleming, P., \& Spicer, A. (2003). Working at a cynical distance: Implications for power, subjectivity and resistance. Organization, 10, 157-179.

Flyvbjerg, B. (2006). Five misunderstandings about case-study research. Qualitative inquiry, $12,219-245$.

Foucault, M. (1979). The history of sexuality, Volume 1. Harmondsworth: Penguin.

Foucault, M. (1988). Technologies of the self. In L.H. Martin, H. Gutman, \& P. Hutton (Eds.), Technologies of the self: A seminar with Michel Foucault (pp.16-49). London: Tavistock.

Fournier, V. (1999). The appeal to "professionalism" as a disciplinary mechanism. The Sociological Review, 47, 280-307.

Frey, J.H., \& Eitzen, D.S. (1991). Sport and society. Annual Review of Sociology, 17, 503522.

Fuller, G., \& Lee, A. (1997). Textual collusions. Discourse: Studies in the cultural politics of education, 18, 409-423.

Gabriel, Y. (1999). Beyond happy families: A critical re-evaluation of the control-resistanceidentity triangle. Human Relations, 52, 179-203.

Gabriel, Y., Gray, D.E., \& Goregaokar, H. (2010). Temporary derailment or the end of the line? Managers coping with unemployment at 50. Organization Studies, 31, 1687-1712.

Gagnon, S., \& Collinson, D. (2014). Rethinking global leadership development programmes: the interrelated significance of power, context and identity. Organization Studies, 35, 645670 . 
Gearing, B. (1999). Narratives of identity among former professional footballers in the United Kingdom. Journal of Aging Studies, 13, 43-58.

Giddens, A. (1991). Modernity and self-identity: Self and identity in the late modern age. Stanford, CA: Stanford University Press.

Gill, M.J. (2015). Elite identity and status anxiety: an interpretative phenomenological analysis of management consultants. Organization, 22, 306-325.

Goffman, E. (1959). The presentation of self in everyday life. Garden City, NY: Doubleday.

Goffman, E. (1963). Stigma: Notes on the management of spoiled identity. Englewood Cliffs, NJ: Prentice Hall.

Grant, D., Hardy, C., Oswick, C., \& Putnam, L.L. (2004). Introduction: Organizational discourse: Exploring the field. In D. Grant, C. Hardy, C. Oswick, and L.L. Putnam (Eds.), The Sage handbook of organizational discourse (pp.1-36). London: Sage.

Grey, C. (1994). Career as a project of the self and labour process discipline. Sociology, 28, 479-497.

Harding, N. (2007). On Lacan and the "becoming-ness" of organizations/selves. Organization Studies, 28, 1761-1773.

Holstein, J.A., \& Gubrium, J.F. (2000). The self we live by: Narrative identity in a postmodern world. Oxford: Oxford University Press.

Humphreys, M. (2005). Getting personal: Reflexivity and autoethnographic vignettes. Qualitative Inquiry, 11, 840-860.

Humphreys, M., \& Brown, A.D. (2002). Narratives of organizational identity and identification: a case study of hegemony and resistance. Organization Studies, 23, 421-447.

Humphreys, M. Brown, A.D. \& Hatch, M.J. (2003). Is ethnography jazz? Organization, 10, 5-31.

Jackall, R. (1988). Moral mazes: The world of corporate managers. Oxford: Oxford University Press.

Keidel, R.W. (1987). Team sport models as a generic organizational framework. Human Relations, 40, 591-612.

Kerfoot, D., \& Knights, D. (1998). Managing masculinity in contemporary organizational life: A “man"agerial project. Organization, 5, 7-26.

Kerkhoff, A.C., \& McCormick, T.C. (1955). Marginal status and marginal personality. Social Forces, 34, 48-55. 
Knights, D., \& Clarke, C. (2014). It's a bittersweet symphony, this life: Fragile academic selves and insecure identities at work. Organization Studies, 35, 335-357.

Knights, D., \& Willmott, H. (1999). Management Lives, Power and Identity in Work Organizations. Sage: London.

Learmonth, M., \& Humphreys, M. (2012). Autoethnography and academic identity: Glimpsing business school doppelgangers. Organization, 10, 99-117.

Lutgen-Sandvik, P. (2008). Intensive remedial identity work: responses to workplace bullying trauma and stigmatization. Organization, 15, 97-119.

Maitlis, S. (2009). Who am I now? Sensemaking and identity in posttraumatic growth. Exploring positive identities and organizations: Building a theoretical and research foundation (pp.47-76). New York: Routledge.

Mangan, J.A. (1996). Games field and battlefield: A romantic alliance in verse and the creation of militaristic masculinity. In J. Nauright \& T.J.L. Chandler (Eds.), Making men, rugby and masculine identity (pp.140-157). London: Routledge.

Mills, W.C. (1970). The sociological imagination. Penguin: Harmondsworth.

Mumby, D., \& Clair, R. (1997). Organizational Discourse. In T.A. van Dijk (Ed.), Discourse as structure and process. Discourse studies vol. 2-A multidisciplinary introduction (pp.181205). London: Sage.

Nauright, J. \& Chandler, T.J.L. (1996). Making men, rugby and masculine identity. London: Routledge.

Newton, T. (1998). Theorizing subjectivity in organizations: The failure of Foucauldian studies? Organization Studies, 19, 415-447.

Petriglieri, J.L. (2011). Under threat: Responses to and the consequences of threats to individuals' identities. Academy of Management Review, 36, 641-662.

Pratt, M.G. (2000). The good, the bad, and the ambivalent: Managing identification among Amway distributors. Administrative Science Quarterly, 45, 456-493.

Pringle, R. (2001). Competing discourses: Narratives of a Fragmented Self, Manliness and Rugby Union. International Review for the Sociology of Sport, 36, 425-439.

Pullen, A. (2007). Becoming a researcher: gendering the research self. In A. Pullen, N. Beech, and D. Sims (Eds.), Exploring identity: Concepts and methods (pp.316-333). London: Palgrave MacMillan,.

Richardson, L., \& St. Pierre, E.A. (2005). Writing. A method of inquiry. In N.K. Denzin \& Y.S. Lincoln (Eds) Handbook of qualitative research (pp.959-978). Thousand Oaks, CA: Sage. 
Ricoeur, P. What is a text? Explanation and understanding. In D. Rasmussen (Ed.), Mythicsymbolic language and philosophical anthropology (pp.135-50). The Hague: Martinus Nijhoff, 1971.

Sennett, R., \& Cobb, J. (1977). The hidden injuries of class. Cambridge: Cambridge University Press.

Snow, D.A. \& Anderson, L. (1987). Identity work among the homeless: The verbal construction and avowal of personal identities. American Journal of Sociology, 92, 13361371.

Speer, S. (2005). Gender talk: Feminism, discourse and conversation analysis. Sussex: Routledge.

Starkey, K.A., \& McKinlay, A. (1998). Afterword: Deconstructing Organization-Discipline and Desire. In A. McKinlay \& K. Starkey (Eds.), Foucault, Management and Organization Theory: From Panopticon to Technologies of Self (pp.230-241). London: Sage.

Stonequist, E.V. (1937). The marginal man. New York: Scriveners.

Strauss, A., \& Corbin, J. (1990). Basics of qualitative research. Thousand Oaks, C.A.: Sage.

Sveningsson, S., \& Alvesson, M. (2003). Managing managerial identities: Organizational fragmentation, discourse and identity struggle. Human Relations, 56, 1163-1193.

Taylor, R. (1995). Discussion with Rogan Taylor at Liverpool University, October, 1. Quoted in B. Gearing (1999) Narratives of identity among former professional footballers in the United Kingdom. Journal of Aging Studies, 13, 43-58.

Thompson, C. J., \& Haytko, D. L. (1997). Speaking of fashion: consumers' uses of fashion discourses and the appropriation of countervailing cultural meanings. Journal of consumer research, $24,15-42$.

Thompson, P. \& McHugh, D. (2002). Work organisations. Houndsmill: Palgrave.

Thornborrow, T., \& Brown, A.D. (2009). 'Being regimented': Aspiration, discipline and identity work in the British Parachute Regiment. Organization Studies, 30, 355-376.

Tolson, A. (1977). The limits of masculinity. London: Tavistock.

Tseelon, E. (1991). The method is the message: On the meaning of methods as ideologies. Theory and psychology, 1, 299-316.

Van Maanen, J. (1979). The fact of fiction in organizational ethnography. Administrative Science Quarterly, 24, 539-550.

Van Maanen, J. (2011). Ethnography as work: some rules of engagement. Journal of Management Studies, 48, 218-234.

Wacquant, L.J. (1995). Pugs at work: bodily capital and bodily labour among professional boxers. Body \& Society, 1, 65-93. 
Wagley, C. (1983). Learning fieldwork: Guatemala. In R. Lawless, V.H. Sutlive, \& M.D. Zamora (Eds.), Fieldwork: The human experience (pp.1-17). New York: Gordon and Breach.

Wainwright, S.P. \& Turner, B.S. (2004). Epiphanies of embodiment: injury, identity and the balletic body. Qualitative Research, 4, 311-337.

Watson, J. (2000). Male bodies, health, culture and identity. Buckingham: Open University Press.

Watson, T.J. (1994). In search of management: culture, chaos and control in managerial work. Routledge: London.

Ybema, S., Keenoy, T., Oswick, C., Beverungen, A., Ellis, N., \& Sabelis, I. (2009). Articulating identities. Human Relations, 62, 299-322.

Young, K., McTeer, W., \& White, P. (1994). Body Talk: Male Athletes Reflect on Sport, Injury, and Pain. Sociology of sport journal, 11, 175-190. 


\section{Notes}

\footnotetext{
' 'Northern Knights' is a pseudonym.

ii There are two principal rugby codes, 'Rugby League' and 'Rugby Union' which have distinct rules, histories, and cultures, and which in the UK are often popularly associated with different 'classes', with Rugby League generally considered to be more 'working class'. Threats to the long-term survival of Rugby League as a sport in the UK were commented upon by interviewees, who acknowledged that the sport was 'not in the limelight' (Director \#3).

iii These data were supplemented by the collection of written materials such as corporate literature, press articles, a wealth of publications focused on sport in general and rugby in particular, and the club's web-site. While these sources, and our observations, provided valuable contextual information which both broadened and deepened our appreciation of the research site, because our principal concern is the identity work engaged in by players, relatively little of this supplementary data are included in this paper.

${ }^{\text {iv }}$ The decision to focus specifically on work identities was taken during the initial framing of the research project in which we decided to investigate the identity work involved in the authorship of professionals' work identities. This decision was grounded in our aim of contributing to the literature on identities and identity work in a work organizational context. This said, our questions were deliberately 'open' and we were not insensitive to the fact that rugby players have other identities, for example, as family members. However, perhaps in part because they were interviewed in a work setting, players only very occasionally mentioned non-work identities and none of these data were relevant to our emergent interest in identity threat and response dynamics.

${ }^{v}$ For rugby players, enacting their desired selves meant more than merely playing rugby, and included also the status, fame and physical conditioning etc. associated with these identities.

vi Our findings here are similar to other studies that have described how injuries may be construed as a threat to people's work identities. Wainwright and Turner (2004: 328) regard career threatening injuries to ballet dancers as '...a major threat to their identity'. Maitlis (2009: 56) asserts that injuries to musicians reveal '...the fragility of this identity'. Gearing (1999: 50) states that injuries to professional footballers which raise the spectre of forced retirement are a '...threat to the player's identity'.
} 